\title{
Horasan Tasavvuf Geleneği Bağlamında Çankırı'da Bir Yesevî Muakkibi
}

\author{
Abdulselam ARVAS ${ }^{1}$
}

$\ddot{O} z$

Bugüne kadar Yesevilik üzerine hazırlanan çalışmalarda Ahmed Yesevî’nin birçok dervişinden bahsedilmiştir. Bununla beraber, XII. yüzyılda Horasan'dan gelip Çankırı'ya yerleşen ve bir Yesevî muakkibi olan Hacı Murad-1 Veli ciddi bir değerlendirmeye tabi tutulmamıştır. Onun için bu araştırmada, Hacı Murad-1 Veli, kendisine dair tüm veriler karşılaştırılmak suretiyle incelenmiştir. Makalede ilkin Yeseviliğin; tasavvuf tarihi ve Horasan tasavvuf geleneğindeki yeri üzerinde durulmuștur. Daha sonra Hacı Murad-1 Veli’ye değinen kaynaklar temelinde onun Yesevilikle bağlantısı irdelenmiştir. Bunun için yazılı belgelerden, maddî kültür unsurlarından (türbe, cami vb.) ve sözlü rivayetlerden istifade edilmiştir. Ayrıca bu çalışmada Hacı Murad-1 Veli’ye ait farklı hayat hikâyeleri tahlil edilmiş ve onun bir Yesevî muakkibi olup olmadığı tartışılmıştır. Bunun en önemli sebebi ise eski yazılı belgelerde onu Yesevî addeden sağlam bir kayda şimdilik rastlanmamış olmasıdır. Kısaca makalede çeşitli kaynaklardan hareketle Hacı Murad-1 Veli’nin Yesevîlikle bağlantısı incelenmiş, bu husus tarihî verilerle de desteklenmeye çalışmıştır.

Anabtar Kelimeler: Tasavvuf, Horasan, Yesevî, Yesevîlik, Çankııı, Hacı Murad-1 Veli

\section{A Yasawî Darwish in Chankiri in the Context of Khorassan Sufism Tradition}

\section{Abstract}

Until today, many darwishes of Ahmed Yasawî have been mentioned in studies prepared on Yasawiyyah. However, Hadji Murad-i Veli, who came from Khorassan and settled in Chankiri in the XII. century and he was a Yasawî follower, was not subjected to any serious evaluation. Therefore, in this research, Hadji Murad-i Veli has been examined by comparing all the data about him. Then, on the basis of the sources referring to Hadji Murad-i Veli, his connection with Yasawî was examined. For this purpose; written documents, material cultural elements (tombs, mosques, etc.) and oral narrations were used. In addition, in this study, different life stories belonging to Hadji Murad-i Veli were analyzed and it was discussed whether it was a Yasawî dervish or not. One of the most important reasons for this is the fact that in the old written documents a solid record showing him as Yasawî has not been found. Briefly in the article, the connection of Hadji Murad-i Veli with Yasawi was investigated through various sources and tried to support this issue with historical evidence.

Key Words: Mysticism, Khorassan, Yasawî, Yasawiyyah, Chankiri, Hadji Murad-i Veli

Atıf İçin / Please Cite As:

Arvas, A. (2020). Horasan tasavvuf geleneği bağlamında Çankırı'da bir Yesevî muakkibi. Manas Sosyal Araştırmalar Dergisi, 9(1), 505-516.

Geliş Tarihi / Received Date: 05.02.2019

Kabul Tarihi / Accepted Date: 17.09.2019

\footnotetext{
1 Prof. Dr. - Çankırı Karatekin Üniversitesi, Edebiyat Fakültesi, Türk Dili ve Edebiyatı Bölümü - aarvas@karatekin.edu.tr ORCID: 0000-0002-7553-183X
} 


\section{Giriş}

Tasavvufî mektepler; bireyi iç yolculuğa yönlendiren, "insan-1 kâmil” yetiştirmeyi amaçlayan ve aynı zamanda İslam tarihinde önemli yer tutan kurumlardır. Bu kurumların temeli ise Hz. Muhammed'den (sav.) sonra, Müslümanların onun gibi yaşama isteğine dayanmıştır. Nitekim İslam tarihinde $\mathrm{Hz}$. Peygamber'i (sav.) yaşantısına örnek edinen İbrahim Edhem (öl. 778), Bişr-i Hâfî̀ (öl. 842), Şakîk-i Belhî (öl. 870) gibi (Eraydın, 1990, s. 74-93) birçok sûfi yetişmiş ve onların etrafinda okul denebilecek tarikatlar

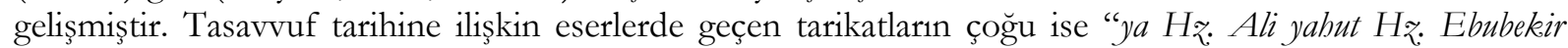
arachlğgyla" (Güzel, 2012, s. 40) veyahut "dört halife vasitasiyla” (Eraydın, 1990, s. 365) Hz. Peygamber'e (sav.) dayandırılmıştır. Onun için tarikatlar başlangıçtan itibaren İslam toplumu üzerinde etkili olmuştur. Müslüman olduktan sonra İslam tarihinde çok etkin rol oynayan Türkler de tasavvufî cereyanlara kayıtsız kalmamış, hatta Yesevîlik, Bektaşilik, Bayramîlik vb. gibi birçok yeni tarikatın ortaya çıkmasına vesile olmuşlardır. Bu kapsamda, XII. asrın önemli mutasavvıflarından Hoca Ahmed Yesevî Horasan tasavvuf geleneği içerisinde yetişmiş olup, onun takipçilerine Yesevî, sonraki asırlarda başka halifeleri tarafından belli bir düzene oturtulan tarikata da Yesevîlik denmiştir.

\section{Horasan Tasavvuf Geleneği ve Ahmed Yesevî}

Horasan'da gelişen Türk tasavvuf geleneğini ve Yesevilliğin ortaya çıkışını anlamak için hem Horasan'ın tarih içindeki seyrine hem de bu bölgede oluşan Horasan tasavvuf geleneğine kısaca bakmak gerekir. Zira İslam'ın ve tasavvufun bölgeye ne zaman geldiği ve burada nasıl kök saldığ1 önemli bir husustur. Peki, Horasan tarihte kimlerin eline geçmiş ve nasıl bir coğrafya olmuştur? Eldeki bilgilere göre Horasan; Hindistan ve İran'a yayılan Hint-Avrupa kökenli Ari ırkın ortaya çıtı̆ğı yerdir. Hunlara ve Göktürklere bağlı çeşitli Türk boyları, Müslüman Araplar ve daha sonra Moğollar da Horasan'a yerleşen unsurlar arasındadır. Araplar ise Hz. Ömer döneminde Kadisiye savaşıyla birlikte Horasan’a girmiştir. Sonraki dönemlerde Arapların etkisi azalsa (Çetin, 1998, s. 235) da İslam'ın buraya nüfuzu artık sürekli bir hâl almıştır. Nitekim bu süreçte Emevî, Abbasî gibi Arapların yanı sıra Fars kökenli Tahirîler ve Samanîler de (Çetin, 1998, s. 235) Horasan'ı yönetir. Horasan, X. asırdan sonra ise Gazneli ve Selçuklu gibi Türk soylu olan Müslüman devletlerin eline geçer. Selçuklular uzun bir müddet buraya hükmeder ve buray1 devletin en önemli kenti hâline getirir. Bölgenin Selçuklulara kadarki tarihini özetledikten sonra Horasan'da oluşan tasavvuf geleneğine de kısaca göz atmak gerekir.

Bu bağlamda Horasan tasavvuf geleneğinin oluşumunu anlamak için Horasan'da intişar eden tarikatlara bakmak araştırmayı tarihî zemine oturtmak bakımından önemli olacaktır. Çünkü tasavvuf; somut kurumlar olan tarikatları, tarikat pirlerini, onların önde gelen temsilcilerini ve takipçilerini kapsamaktadır. Buna göre; Ahmed Yesevînnin içine dâhil olduğu ve Hz. Peygamber'e (sav.) ulaşttğı söylenen Horasan tasavvuf geleneği silsilesi şöyledir: "H₹. Mubammed (sav.), H₹. Ebubekr (r.a.), Selman-ı Farisî, Kasım b. Muhammed es-Sıddlk, Cafer-i Sadık, Bayerid-i Bistamî, Ebu'l-Hasan Harkanî, Ebu Ali Faremedî, Yusuf-ı Hemedan厃̀' (Eraydın, 1990, s. 367). Bu tarikat silsilesinde Ahmed Yesevî, Yusuf Hemedanî’nin talebesi olarak karşımıza çıkmakta ve böylece Yesevîlik, Horasan tasavvuf geleneğine bağlanmış olmaktadır. Ahmed Yesevî’nin, Yusuf Hemedanî̀ye intisap ederek onun nüfuzu altında yetişmesi (Eraydın, 1990: 371) onu Horasan Türk tasavvuf geleneğinin önde gelen temsilcisi yapmıştır. Nitekim hem Yesevî hem Nakşibendî geleneğine göre onun Türk illerinin dört bir tarafına yolladığı çok sayıda talebesi olmuştur. Bunların içinden Rum diyarına gönderdiği halifeler arasında Avşar Baba, Akyazıll, Kıdemli Baba Sultan, Geyikli Baba, Abdal Musa, Horos Dede (Köprülü, 1976: 46-48) vb. gibi isimler bulunmaktadır. Ancak bu dervişlerin geliş tarihi hakkında kaynaklarda kesin bilgi verilememektedir. Bununla beraber Pir Dede, Emir Çin Osman, Şeyh Nusret, Gajgaj Dede gibi kişilerin ise Kuzey Anadolu'da (Köprülü, 1976, s. 46-48) faaliyet göstermesi dikkat çekmektedir.

\section{Horasan Tasavvuf Geleneğinde Hac1 Murad-1 Veli'nin Yeri}

Araştırmanın bu kısmına kadar üzerinde durulan hususların temel amacı Yesevîliğin Horasan tasavvuf geleneğiyle ilişkisini ve menşeini, Yesevî dervişlerinin nerede, nasıl yetiştĭgini ve hangi coğrafyalara dağıldığını tarihsel ve bilimsel bir zemine oturtmaktı. Nitekim yaygın kanaate göre Anadolu'ya ulaşan Yesevî dervişler Horasan üzerinden gelmiş ve Anadolu'nun dört bir tarafina dağılmıştır. Böylece Ahmed

\footnotetext{
2 Elbette Yusuf Hemedanî̀ye kadar Horasan tasavvuf geleneğini temsil eden çok sayıda mutasavvıf vardır. Onların hepsinden bahsetmek araştırmanın sınırlarını aşacağı için burada sadece bir tarikat silsilesi ele alınmıştır. Çünkü makalede Yesevilliğe iliş̧kin bir konu incelenmiştir. Bu husus ise Yusuf Hemedanî’yi ilgilendirdiği için burada sadece onun tarikat silsilesi verilmiştir. Bu silsilenin haricinde Yusuf Hemedanî’nin Hz. Ali (r.a.) ile Hasan-1 Bastr̂’den (Eraydın, 1990, s. 368) gelen iki silsilesi daha vardır.
} 
Yesevî muakkipleri, bir taraftan Orta Asya'dan Kazakistan'ın kuzeyine ve Deşti Kıpçak'a, öte taraftan Horasan üzerinden Azerbaycan ve Anadolu topraklanına farklı göç yollarını kullanarak ulaşmıştır. Bu minvalde özellikle Kuzey Anadolu'da çok sayıda Yesevî dervişin bulunması Yesevîliğin buradaki etkisi bakımından dikkat çekicidir. Ancak yazılı kaynaklarda Ahmed Yesevî’nin Kuzey Anadolu'da faaliyet gösteren dervişleri arasında ne Hac1 Murad-1 Veli ismine ne de ona dair herhangi bir bilgiye rastlanmaktadır. ${ }^{3}$ Buna karşın az önce ifade edildiği üzere Kuzey Anadolu’ya onun çok sayıda dervişi geldiğine göre Çankırı ve civarında faaliyet gösteren ve sözlü gelenekte Ahmed Yesevî muakkibi olduğu söylenen Hacı Murad-1 Veli'nin de bu dervişler arasında olma ihtimali yüksektir. ${ }^{4}$

Başka deyişle, Hacı Murad-1 Veli hakkında doğrudan bilgi veren eski yazma veya matbu eserler bulunmadığını belirtmek gerekir. Bundan dolayı bu mutasavvıfla ilgili kati bir hüküm ileri sürmek zor olmaktadır. Ancak eski yazma veya matbu eserlerin yokluğu, bu mutasavvif hakkında bilgi bulunmadığ1 anlamına gelmez. Çünkü söz konusu kaynaklar haricinde sözlü gelenek aktarıcısı olan kaynak kişiler ile maddî kültür unsurları Hacı Murad-1 Veli'nin bu bölgede yaşadığına dair kuvvetli ipuçları sunmaktadır. Üstelik sözlü geleneğe dayalı bilgilerin tamamen mesnetsiz olmadığını da hatırlatmak gerekir. Buna göre Hacı Murad-1 Veli'yi Ahmed Yesevî ve Yesevîlik vasıtasıyla Horasan'da gelişen Türk tasavvuf geleneğine bağlayan kaynaklara göz atmakta fayda var. Bunun için de evvela eski tarihli arşiv belgelerine, sonra maddî kültür unsurlarına ve en sonunda ise sözlü geleneğe dayalı yapılmış çalışmalara bakmak suretiyle bu mutasavvıftan söz eden ve onu Horasan tasavvuf geleneğine bağlayan kaynakları incelemek ve onları tahlil etmek gerekir.

\section{Eski Tarihli Belgeler (Arşiv Belgeleri, Vakfiyeler, Yazmalar vs.)}

Şimdilik tespit edilen eski tarihli belgelere (arşiv, vakfiye kayıtları, el yazma vb.) bakınca Hacı Murad-1 Veli'den bahseden beş belgeyle karşılaşılmaktadır. Murat Karadut'un yayımladığ bu belgeleri ${ }^{5}$ kronolojik olarak şöyle siralamak mümkündür:

A) Ferman: Hacı Murad-1 Veli'nin soyundan gelenlerin Çankırı Sancağına dilekçe vererek vergiden muaf olma isteklerini belirten bir belgedir. Belge, Hicri 1145 [M. 1732] tarihlidir (Karadut, 2014, s. 37).

B) Kastamonu Valisine yazılan mektup: Bu mektupta Kastamonu’ya bağlı Ahlatçık Köyü’nde Hacı Murad-1 Veli'ye ait bir vakfin bulunduğu ve tasarrufunun Ahmet Hayati ve kardeşlerine ait olduğu ama yarı hissenin Bekiroğlu Ahmet Ağa’ya geçtiği yazılıdır. Ahmet Hayati ve kardeşleri kendilerine düşen hissenin payın vekil tayin ettikleri Mehmet Fehmi Efendi'ye teslim edilmesini isterler. Belgenin tarihi ise Hicri 1268 [1851] ile 1275 [1858] y1llarına aittir (Karadut, 2014, s. 26).

C) Mektubun cevabı: Ahmet Hayati ve kardeşlerinin Kastamonu Valisine yazdığı mektuba olumlu cevap verilen bu belge de tarih olarak aynı y1llara aittir (Karadut, 2014, s. 25).

D) Varidat cetveli: Burada, Hacı Murad-1 Veli Vakfina ait Hicri 1300 [1882] tarihli bir gelir listesi vardır (Karadut, 2014: 30).

E) Hatt-1 hümayun: Seydi Köyü'ndeki Abdulgaffar Çelebi Vakfi'nda bulunan bu hümayunun, Abdulgaffar'ın mirasçısı olmayan Halil'e ve İsmail'e verildiği anlatılır. Belge, Hicri 1307 [1889] ve 1308 [1890] tarihlerini taşımaktadır (Karadut, 2014, s. 29).

Murat Karadut'un neşrettiği bu belgelerin en eski tarihlisi I. Mahmut dönemine yani Miladi 1730’lu tarihlere uzanan ve Hac1 Murad-1 Veli'nin soyundan gelenleri vergiden muaf tutan bir belge olarak görünmektedir. Diğer belgeler ise daha yakın döneme denk gelmekte ve ya Hacı Murad-1 Veli’ye ya da onun çocuklarına ait vakfiyelerden bahsetmektedir. Oysa Hacı Murad-1 Veli’nin ölüm tarihi yaygın rivayete göre M. 1207, başka bir rivayete göre ise M. 1307 olarak ifade edilmektedir. Bu tarihler arasında 400 ila 500 ylldan fazla bir zaman fark1 var. Üstelik bu kaynaklar Hac1 Murad-1 Veli ile ilgili doğrudan bilgi veren belgeler de değildir. Onun için bahsedilen yazılı kaynaklar hem bu mutasavvifin yaşadığı tarihler

\footnotetext{
3 Hacı Murad-1 Veli hakkında ne menakıpnamelerde ne velayetnamelerde ne de tarihî eserlerle seyahatnamelerde bilgi bulunmaktadır. Bundan dolayı da bu mutasavvıf hakkında şimdiye kadar ciddi hiçbir bilimsel araştırma yapılamamıştır. Buna rağmen Çankırı ve çevresindeki sözlü rivayetler Hacı Murad-1 Veli’yi Horasan Türk tasavvuf mektebine, özellikle de Yesevîliğe bağlama eğilimindedir.

${ }^{4}$ Son dönemde yazılan birkaç makalede de onun Ahmed Yesevî halifesi olduğuna dair kanaatler dile getirilmiştir (Arslanoğlu, 1999, s. 68; Yaman, 2005, s. 155; Akyol, 2012, s. 69). Ancak bu kanaatlerin de yaz1l kaynaklardan ziyade sözlü geleneğe dayandığını ifade etmek gerekir.

${ }^{5}$ Murat Karadut, neşrettiği belgelere herhangi bir isim vermemiş, onları "Belge-1, Belge-2” vs. şeklinde numaralandırmıştır. Ancak makalede, bu belgelerin içeriğine bakılarak adlandırıldığını ifade etmek gerekir.
} 
konusunda zayıf kalmakta hem de onu Horasan tasavvuf geleneğine bağlayan en ufak bir imay1 içermemektedir. Dolayısıyla yazılı belgelerde Hacı Murad-1 Veli'nin ne kimliği ne de Yesevîlikle bağlantısına dair bir bilgi mevcuttur.

Bu arşiv belgeleri haricinde Rumî 1280 (M. 1864) tarihli 19385 numaralı Cankır Evkaf Defterinde "Kara Seydi Karban Saray Vakfı" ile "Abdulgaffar Çelebi Vakfı"nın adları geçmektedir (İpçioğlu, 2009, s. 16). Bu iki vakıf belgesi Osmanlı Devleti'nin son zamanlarına kadar da geçmişin somut bir hatırası olarak Hacı Murad-1 Veli'yi ve oğlunu kaydeden belgeler arasında yer almıstır. Bu yüzden bu evkaf defterindeki adı geçen vakıflar Hacı Murad-1 Veli’nin tarihî kişiliğine bir delildir. Vakfiye tarihine göre 1463’te kurulan ve Çankırı'ya bağlı Derekayı ile Dümeli adlı köylerin gelirlerinin yarısının Türbe adlı köydeki zaviyeye (Abdulgaffar Çelebi Zaviyesi kast ediliyor) bağışlandığı (Kankal, 2011, s. 208) bir kayıt daha vardır. Sadece evlada vakıf (Kankal, 2011, s. 208) olduğu kaydının bulunması da buranın şimdi de türbede metfun olan Abdulgaffar Çelebi ile doğrudan, Hacı Murad-1 Veli ile ise dolaylı yoldan ilişkili olduğu intibaını vermektedir. Bu belgeler tarihî açıdan çok önemli olsa da mutasavvifin Horasan tasavvuf geleneğiyle ilişkisini maalesef aydınlatamıyor.

H. 698'de [M. 1298] Elvan Seydi b. Musalih Seydi', Kalecik’in Elmalı Köyü'nde "Elvan Seydi Zaviyesi"ni kurmuş ve buraya Yamacıoğullarından Mahmud Beğ b. Mehmed Beğ ile Candaroğlu Kasım Bey de birer çiftlik bağıslamıştır. Son tahrirde şeyhin sülalesinden "2 zaviyedar" ve "31 evlad-1 şeyh" (Kankal, 2011, s. 210) kaydı yer almaktadır. Ahmet Kankal'ın dediği gibi 31 kişinin şeyhin sadece müridi olduğu fikrine katılmak mümkün değil. Bunların, Elvan Seydi b. Musalih Seydi’nin ailesi ve yakın akrabaları ama aynı zamanda müridi olduğu tahmin edilebilir. Yine, Kalecik'in Elmalı Köyü'nde, 1530'dan sonra yapılan "Elvan Seydi Mescidi" (Kankal, 2011, s. 200) de dikkate alınmalıdır. Ahmet Kankal (2011, s. 210) Elvan Çelebi'nin dervişlerinden birinin Çankırı Pelidözü civarında onun adına "Elvan Çelebi Zaviyesi" kurduğuna dair bir bilgi daha vermektedir. ${ }^{7}$

Kurşunlu ilçesinde bir tane daha "Şeyh Elvan Zaviyesi” (Kankal, 2011, s. 216) bulunmaktadır ki bu da büyük ihtimalle Hacı Murad-1 Veli'nin oğlu Elvan Seydi ile ilişkilidir. Demek ki Hacı Murad-1 Veli'nin çocukları içinden en meşhur olanı Elvan Çelebi'dir. Bundan dolayı onun adına kayda geçen dört adet mekân vardır. Yakın civarda bulunan Elvan Seydi ismine ait bu tarz mescit ve zaviyeler ile Eldivan (Dümeli) ilçesinde Abdulgaffar Çelebi adına kayıtlı bir zaviyenin varlığı Hacı Murad-1 Veli'nin tarihte yaşamış bir zat olduğunu ispatlamaktadır. Bu mutasavvıfın yaşadığını ispatlayan başka bir delil ise arşivlerde Seydiköy adının XVI. asırlara (Kökel-Ersal, 2008, s. 26; Kankal, 2011, s. 52) yani 1530’lu yıllara kadar gitmesidir. Gene XVI. asırdaki tahrir defterlerine bakıldığında da Seydiköyº, vakıf (Kankal, 2011, s. 93, 254) olarak geçmektedir. Ö. Lütfi Barkan'ın (y.t.y.: 40) da belirttiğgi gibi bir köyün vakıf olabilmesi için orayı imar edenin topluma yararlı (dinî, dünyevî vb. gibi) işler yapmasını gerektirmektedir.

Binaenaleyh kayıt altına alınmış bütün bu bilgiler bize önemli bazı ipuçları vermektedir. Mesela bu kayıtlar Hacı Murad-1 Veli’nin çocuklarının mürşitlik vazifelerini göstermesi bakımından önemli olup konuyla ilgili sözlü rivayetleri desteklemektedir. Ayrıca bu bilgiler Hacı Murad-1 Veli'nin etrafinda oluşan bir geleneği de bildirmektedir. Yine de bu bilgiler onun Horasan tasavvuf geleneği ve Ahmed Yesevî̀yle bağlantısı için yeterli olmamaktadır. Kısaca buraya kadarki yazılı kaynaklar Hacı Murad-1 Veli’nin tarihî kişiliğine ş̧ık tutsa da onun Yesevilikle bağlantısına dair hiç bilgi vermemektedir. Dolayısıyla konuyla ilgili yazılı kaynakların istediğimiz bilgileri vermekten uzak olduğu görülmektedir.

\section{Maddî Kültür Unsurları (Türbe, Taş, Cami, Börk vs.)}

\footnotetext{
${ }^{6}$ Bu şahıs, büyük ihtimalle, Hacı Murad-1 Veli’nin oğlu Elvan Çelebi’nin (Elvan Seydi) torunu olup dedesinin adını taşıyan bir zaviye kurmuştur. Musalih Seydi'nin oğlu olduğunu tahmin ettiğimiz bu şahsın, zaviyeyi dedesinin babası Hacı Murad-1 Veli adına değil de, dedesi Elvan Çelebi adına kurması farklı şekillerde değerlendirilebilir. Bize göre ise bu durum, Elvan Çelebi'nin bu dönemde daha meşhur olmasıyla ilişkilidir. Bu şahsın, Elvan Çelebi'nin torunu olduğuna dair kanaatimiz ise aile içinde isim verme geleneğinden ileri gelmektedir. Yaygın bir gelenek olan bu husustan ötürü Musalih Seydi, kendi çocuğuna babasının adını koymuş olmalıdır. Ayrıca Hacı Murad-1 Veli'nin oğlu Elvan Seydi'ye ait bu zaviyeye Candaroğlu Kasım Bey tarafindan yardımda bulunulduğu (Kankal, 2011: 189) belirtilmektedir. Muhtemelen bu zaviye Elvan Seydi b. Musalih Seydi’nin kurduğu yapıdır. Nitekim Kasım Bey’in hüküm sürdüğü yıllar (1440-1464) dikkate alındığında zaviyenin kuruluş tarihlerinin daha önce olacağında şüphe yoktur.

7 Araştırmacı, buranın Çorum'un Mecitözü ilçesinde bulunan "Elvan Çelebi Zaviyesi” ile aynı olup olmadığından şüphe duymaktadır (Kankal, 2001, s. 210).

${ }^{8}$ Halk arasındaki sözlü rivayetler köyün adını, genellikle Hacı Murad-1 Veli’nin seyyidliğiyle ilişkilendirmektedir.
} 
Geçmişte yaşayan şahıslara dair araştırmalar yapılırken onlara atfedilen maddî kültür unsurları da önemli ipuçları içermektedir. Bu yüzden Hacı Murad-1 Veli hakkında bir çalışma yapılınca yazılı belgelerin haricinde bilgi veren maddî unsurlara da bakmak gerekmektedir. Nitekim bu unsurları değerlendiren çoğu araştırmacı Hacı Murad-1 Veli'yi bunlar aracillğgyla Ahmed Yesevî̀ye ve Horasan tasavvuf geleneğine bağlamaktadır. O yüzden bu kaynaklara da müracaat etmek gerekir. Maddî kültür unsurlarının ilk ve en önemlisi bugün de ayakta olan Seydi Köy'deki Hacı Murad-1 Veli’ye ait cami ve türbedir. Minberin bulunduğu kısmın diş cephesinde etrafı camla muhafaza edilen ve Hicri olduğu anlaşılan 1291 [1874] tarihi hâlâ kayıtlıdır. Demek ki 1951'de cami tamiratı yapılsa da bu levhanın üstü kapatılmamıştır.

Hacı Murad-1 Veli'nin, köyde bulunan ve ahşap olarak yapılan caminin yanı başındaki türbenin içinde yattığı, cami ve türbenin tezyinatının bir zamanlar çok güzel olabileceği, yakın zamanlardaki onarım sırasında üzerinden geçilerek bozulduğu (Tatc1, 1997, s. 591) söylenmektedir. Cami ve türbenin kitabesinin kaybolduğunu belirten M. Tatcı, bunların yapilıs tarihlerini öğrenemediğini ama bu eserlerin ilk biçiminin 1207'den sonra inşa edildiğini, her iki yapının yüzylllar içinde defalarca tamirat görmüş olabileceğini (Tatc1, 1997, s. 593) ifade etmektedir. M. Tatc1 (1997, s. 594) caminin imamından yapının fiziksel görünümü hakkında aldığ1 bilgileri de çalışmasında vermiştir. Bahattin Ayhan ise "Hac1 Murad-1 Veli Türbesi" başlı̆̆ını (2012, s. 110) kullandığı hâlde cami ve türbenin fizikî yapısı hakkında bilgi vermemiştir. Topkaraoğlu (1991, s. 156-157) kaynak vermeden caminin fizikî yapısına dair bilgiler vermiştir. M. Karadut (2007, s. 17) cami ve türbe hakkındaki bilgileri tekrarlamış ve kaynak belirtmeden caminin 1451 yılında inşa edildiğini ifade etmiştir (Karadut, 2014, s. 100). Cami ve türbenin fizikî yapısı hakkında bilgi veren başka bir kaynak da "Çankırı Kültür Envanteri”" adlı çalısmadır. Ancak çalışmada, bu iki mekânın yapılış tarihi hakkında bilgi verilmemektedir (Şahin vd., 2014, s. 360). Bu kaynağın yararlandığı çalışmalar ise Başer (y.t.y) ve Topkaraoğlu'dur (1991). E. Aydın (2010, s. 82) da cami ve türbe için benzer ifadeleri kullanmakla beraber kaynak göstermeden yapının Osmanlı dönemine ait olduğunu belirtir.

Türbe ve cami dışında bir diğer maddî kültür unsuru da "horasani börk" 9 denilen taşlardır. Köyün mezarlığından getirilen "horasani börk" (sarı) sembollü iki mezar taşı şimdi caminin avlusunda (Tatc1, 1997, s. 591) bulunmaktadır. Köylülerin ve çevredeki insanların bundan hareketle Hacı Murad-1 Veli’nin Horasan menşeli bir alperen olduğunu ima ettiklerini belirten $\mathrm{M}$. Tatcı taşların bu mutasavvıf için sonradan dikilmiş olabileceğini de dile getirmekte ve çevrede Horasan menşeli başka alperenlerin de olabileceğini ileri sürmektedir (Tatc1, 1997, s. 591). Bu hususla ilgili çelişkili ifadeler kullansa da E. Aydın'ın (2010, s. 86), Eldivan'ın başka yerleşim yerlerinde bulunan "horasani börk" örneklerini (2010, s. 127-129) tespit etmesi kayda değerdir. Çünkü somut kültürel kanıtlar olan bu börklerin Eldivan'ın değişik yerlerinde bulunması Horasan erenlerinin varlığına işaret etmektedir. B. Ayhan (2012, s. 111) ise bir cümleyle "horasani börk" meselesine değinmektedir. M. Karadut da türbedeki "horasani börk"lerin Seydiköy, Sarayköy, Gölez vb. başka yerlerde bulunduğunu, bunların Hacı Murad-1 Veli soyundan gelenleri temsil ettiğini ve bu bölgelerde yaşadıklarını gösteren bir kanıt olduğunu dile getirmektedir (Karadut, 2014, s. 56).

Hacı Murad-1 Veli hakkındaki başka bir maddî kültür unsuru ise "yada" taşlarıdır. Bunlar hakkında ilk bilgileri Hikmet Tanyu vermektedir. ${ }^{10} \mathrm{H}$. Tanyu, Hacı Murad-1 Veli türbesinin başucunda dörtgen şeklinde 2 tane büyük siyah taş olduğunu, bunların eskiden 3 adet olduğunu ve taşlardan birinin İstiklal savaş1 sırasında şehit olduğunu (Tanyu, 1968, s. 116) belirtmektedir. Bunlara gök taşları da diyen M. Tatc1 "Türbenin ön tarafinda iki kutsal "yada" tassı vardır. Bunlardan biri çalınmıstır" demektedir (1997, s. 594). E. Aydın ise Seydi Köy nüfusuna kayıtlı Satılmış Işık adlı kaynak kişiye dayanarak Hacı Murad-1 Veli'nin bu "yada" taşlarını Horasan'dan hocası Ahmed Yesevî̀nin görevlendirmesi neticesinde onun dergahından dört yıl gibi bir sürede deveyle Anadolu’ya getirdiğini belirtmektedir. Araştırmacı, taşların getirildiği şehri ise bazen Yesi bazen Horasan olarak ifade etmektedir (Aydın, 2010, s. 86). B. Ayhan (2012, s. 111) da bir cümleyle "yada" taşlarına değinmektedir. M. Karadut "yada" taşlarının Ahmed Yesevînin dergahından geldiğini söylemektedir (Karadut, 2014, s. 56). Bu bilginin ise E. Aydın'dan alındığı görülmektedir. Kısaca gerek kaynaklarda yer alan gerekse hâlâ ayakta dimdik duran maddî kültür unsurları Hacı Murad-1 Veli adlı bir mutasavvıfin dinî ve tasavvufî faaliyetlerine yönelik somut bilgiler aktarmasa bile onun tarihte yaşayan bir şahıs olduğunu göstermektedir.

\section{Sözlü Veriler Temelinde Yapılan Bazı Çalışmaların Hacı Murad-ı Veli’ye Bakışı}

\footnotetext{
${ }^{9}$ Horasani börkler tarihî seyir içinde çok farklı şekiller almıştır ancak Hacı Murad-1 Veli türbesindekiler, bunların en eskisi ve orijinali olmalıdır. Çünkü bu dönem Müslüman Türklerin Anadolu'ya geldiği ilk devirlerdir.

${ }^{10}$ Halk inanışları temelinde bir araştırma yapan H. Tanyu, Seydi Köyde'ki bu taşlarla ilgili bilgilerin kaynağını vermemektedir ama büyük ihtimalle $\mathrm{H}$. Tanyu da halk arasındaki rivayetleri duymuş ve bunu kitabına almıstır.
} 
Esas itibarıyla Hacı Murad-1 Veli’yi Horasanlı bir eren ve aynı zamanda Ahmed Yesevî’nin muakkibi sayan bilgiler daha ziyade sözlü verilere dayanmaktadır. Sözlü verileri temel alan çoğu araştırmacı da neşrettiği kitap, kitap bölümü, risale, makale, bildiri vb. çalışmalarda Hacı Murad-1 Veli'yi bir Yesevî dervişi olarak ifade etmiştir. Bu bağlamda sözlü bilgilerin yer aldığı ilk çalışma "Karatekin Uluları" adlı risaledir. Kitapçı̆ı̆n yazarı Tayip Başer, Hacı Murad-1 Veli’nin babasıyla Türkistan'dan geldiğini yazmakta ve onu Necmeddin Mahmud-1 İsfahani ve Şeyh Bedrettin-i Mahmut vasıtasıyla (Başer, y.t.y.: 19) Horasan tasavvuf geleneğine bağlamaktadır. Mustafa Tatcı meseleye daha ihtiyatlı yaklaşarak Anadolu fütuhatına yönelik araştırmalarda Hacı Murad-1 Veli’nin sadece isminden bahsedildiğini ve türbeye yazılan kitabedeki bilgilerin T. Başer'den alındığını ancak sıhhatli olmadığını (1997, s. 592) ifade eder. Yine de bu araştırmacı onu Horasanlı alperenlerden biri kabul eder (Tatc1, 1997, s. 594).

İbrahim Arslanoğlu, Hacı Muradı Veli'nin 1228 veya 1229'da Horasan'ın Sayram Kasabası'nda dünyaya geldiğini ve bu nedenle Horasan erenlerinden olduğunu söylemektedir (Teberoğlu, 1998, s. 135136'dan Arslanoğlu, 1999, s. 69). "Orta Anadolu Evliyaları" adlı ansiklopedik eser dikkatle incelenince, bu eserin Hacı Murad-1 Veli’ye dair verdiği bilgileri T. Başer ile H. Teberoğlu'na dayandırdığı, dolayısıyla yaygın kanaate katıldığ1 anlaşıllyor (Ayvallı vd., 2004, s. 235-236). Ali Yaman ise Hülya Taş'in (2000) bildirisine ve kendisinin yaptı̆ğ alan araştırmasında gördügü kitabeye ${ }^{11}$ dayanarak bu zatı Horasan tasavvuf ekolüne bağlamaktadır (Yaman, 2005, s. 155). Murat Karadut, hazırladığ1 "Hac1 Murad-1 Veli/Seydi Köyü" adlı kitapçı̆̆ın sekiz farklı yerinde Hacı Murad-1 Veli'yi anlatmakta ve onu Horasan geleneğine bağlamaktadır (Karadut, 2007, s. 14, 17, 19, 20, 21, 23, 26, 83). Eserde onun Çankırı'ya 1117 veya 1228'de yerleştiği, Ahmed Yesevî̀nin müritlerinden olduğu, Hacı Bektaş-1 Veli'den hilafet aldığı (Karadut, 2007, s. 17) gibi bilgiler de bulunmaktadır. Kısaca Murat Karadut çeşitli kaynaklardan hareketle Hacı Murad-1 Veli'nin hem bir Horasan ereni hem de Ahmed Yesevî muakkibi olduğunu yazmaktadır. Araştırmacı, 2014 yılında genişleterek yayımladığı yeni kitapçıkta da aynı bilgileri tekrarlamaktadır.

C. Kökel ve M. Ersal'ın kaleme aldığı makalede genel olarak Çankırı'nın Alevi olan köylerinden bahsedilmiş ve hangi köyün hangi ocağa bağlı olduğu tespit edilmiştir. Burada sözlü kaynaklardan derlenen bilgilerden hareketle Hacı Murad-1 Veli’den söz edilmektedir. Yazıda, bu mutasavvıfın halk arasında Horasan ereni kabul edildiği ve XIII. yüzyılda yaşadığı (Kökel-Ersal, 2008, s. 22, 26) belirtilmektedir. Elvan Aydın ise çalışmasında Hacı Murad-1 Veli ile birlikte pek çok konuya değinmiştir. Kitabının yaklaşık 20 farklı yerinde bu mutasavviftan bahseden E. Aydın, genelde bilindik bilgileri, menkıbeleri ve somut kültürel unsurları (cami, türbe, horasani börk, "yada taşı" vb.) tekrarlamıştır. Kısaca E. Aydın da bu mutasavvifi Horasan ereni ve Ahmed Yesevî muakkibi görmektedir (Aydın, 2010, s. 35-49, 50-60, 80-82, 84, 86, 134). "Çankırı Tasavvuf Tarihine Genel Bir Bakış" (Aktaş, 2011 s. 45-52) başlıklı makalenin yazarı Çankırr'da geçmişte faaliyet gösteren tarikatlardan bahsetmekte ve Yesevilliği ilk sıraya koymaktadır. Makalede Hacı Murad-1 Veli bir Yesevî temsilcisi, babası Aliyü’l-Büka ise Kadiriliğin temsilcisi (Aktaş, 2012: 48) olarak gösterilmektedir.

Bahattin Ayhan, "Çankırı İnanç Rehberi" isimli eserinde Hacı Murad-1 Veli ile ilgili genel bilgileri özetlemektedir. Ayhan'ın bir kısım bilgiyi türbe için hazırlanan levhadan aldığı, diğer bilgiler içinse kaynak göstermediği dikkat çekmektedir (Ayhan, 2012, s. 110-112). Çalışmasında B. Ayhan da Hacı Murad-1 Veli'nin Horasan ereni ve Ahmed Yesevî talebesi (2012, s. 110) olduğu kanaatindedir. Bildirisinde Beylikler dönemi Çankırı'sında dini-tasavvufi hayatı anlatan İbrahim Akyol ise Hacı Murad-1 Veli, babası Aliyü'lBüka, çocukları Abdulgaffar Çelebi ve Elvan Seydi zaviyelerine dair bilgiler vermekte ve genelde benzer bilgileri (Akyol, 2012, s. 69) tekrar etmektedir. İ. Akyol, Hac1 Murad-1 Veli'nin babas1 Aliyü'l-Büka'y1 ise Abdulkadir Geylani’nin halifelerinden Şeyh Baka olarak (Akyol, 2012, s. 69) göstermektedir.

Neticede sözlü rivayetler temelinde ortaya konulan bütün bu çalışmalar Hacı Murad-1 Veli’yi Yesevî muakkibi olarak kaydettiği hâlde bunu destekleyecek herhangi bir belgeye rastlanmamıştır. Ancak Hac1 Murad-1 Veli’nin halk arasında Ahmed Yesevî’nin talebesi olduğuna dair güçlü inanç, araştırmacıları bu kanaate sürüklemiş görünmektedir.

\section{Bulgular ve Tespitler}

\footnotetext{
11 Araştırmacının bahsettiği kaynağın klasik kitabeden ziyade yakın zamanlarda üzerine bilgi yazılan bir levha olduğu anlaşıyor. Çankırı'da buna benzer levhalar Emir Karatekin ve Hacı Murad-1 Veli için de yapılmış olup yapının girişine asılmıstır.
} 
Buraya kadarki tartışmalardan anlaşılacağ1 üzere Hacı Murad-1 Veli'ye ilişkin bilgi veren çeşitli kaynaklar bulunmaktadır. Ancak kaynaklar mukayeseli ve sistematik biçimde incelenmediği için adı geçen mutasavvıfa yönelik bilgiler sağlam bir temele oturtulamamıştır. Şimdiyse Hacı Murad-1 Veli hakkında çeşitli kaynaklardan derlenen bulgular ve ortaya çıkan iki farklı görüş (Sünni ve Alevi) tarihî, kültürel ve etimolojik bilgiler ışında tartışılabilir, yapılacak mukayeselerle elde edilen tespitler aktarılabilir. Ancak bu tespitleri aktarabilmek için öncelikle iki bakış açısına göre Hacı Murad-1 Veli'nin hayat hikâyesini karşılaştırmak üzere özetlemek faydalı olacaktır. Bu bağlamda onun ilk hayat hikâyesi (Sünni) şöyledir:

Horasan erenlerinden Hacı Murad-1 Veli (d. 1117 - ö. 1207) Türkistan'dan gelerek önce Hicaz, Şam ve Şanlıurfa civarlarına, sonra da Çankırı ve Tosya bölgesine yerleşen Aliyü’l-Büka'nın oğludur. Aliyü'lBüka uzun müddet Halilurrahman'da kapıcıllk yapmış, daha sonra Ilgaz'a göçüp yerleşmiştir. Orta kazasının Elmalı Köyü'nde Hasan Doğan tarafindan kopyası alınan şecereye göre Hacı Murad-1 Veli XII. yüzyılda yaşamış, çevresinde İslamiyet'in yayılması için çalışmış, arzu edenleri irşat etmiştir. Hocaları Türkistan'da yetişmiş âlimler olan Hacı Murad-1 Veli, Necmettin Mahmud-1 İsfahani'den, Şeyh Bedrettin-i Mahmut'tan ders almıştır. Hacı Murad-1 Veli 1117'de doğmuş, 1187'de Seydi Köyü'ne yerleşmiştir. Onun bu bölgede Müslümanlığı yayma çalışmaları olmuştur. Türbesi halk tarafindan ziyaret edilen mutasavvıfın üç oğlu vardır. Abdulgaffar, Seydi Köyü’nde babasının türbesi yanındadır. Pir Ali Çelebi'nin mezarı Çubuk'un Selek Köyü'ndedir. Elvan Seydi ise Orta'nın Elmalı kasabasına yerleşmiş ve burada vefat etmiştir (Başer, y.t.y., s. 16-19).

Bu zatın ikinci hayat hikâyesi (Alevi) ise şöyledir:

Hacı Murad-1 Veli 1228 veya 1229'da Horasan'ın Sayram Kasabası'nda dünyaya gelmiştir. Bu nedenle Horasan erenlerindendir. Yaşına girmeden Kâbe yollarında iken "Hille" yakınında annesi vefat etmiştir. Annesi ölmeden önce küçük Ali'yi kendi ocaklarında rehber olan Arap Ali'ye emanet etmiştir. Ali kafileden önce Kâbe'ye ulaştı̆̆ için hacıllğ̆ bir yaşlarından önce almış ve her isteyenin muradını verdiği için de "Murat" adını almıştır. Hac dönüşünde babası Aliyü’l-Büka, kösesinin peşine gitmemiş ve Urfa'da Halilurrahman Türbesi'nde türbe bekçiliği yapmak için kalmış ve oğlu küçük Ali'yi Arap Ali ile Anadolu'ya göndermiştir. Babasının asıl adı S. Ahmet'tir. Ahmed Yesevî’nin türbesinde çok carı çaldığ için halk arasında "Aliyü'l-Büka" olarak bilinir. O, Hacı Ali Türabi'nin kız kardeşinin oğludur ve asıl adı Ali’dir. Hacı Murad-1 Veli, Anadolu’ya Akkoyunlu Aşireti’nin imamı olarak gönderilmiştir. Horasan'dan atılan Karaağaç kösesi, bugünkü adıyla Baykuş Boğazı'nın sağ tarafindaki kayalık alanın az ilerisinde, Eskiköy diye bilinen yerde bulunmuş ve buraya yerleşmiştir. Uzun süre Eskiköy'de yaşamış ve Kalecik tekfurunun zulmüne uğrayarak bugünkü Çankırı'ya bağlı Eldivan ilçesinin Seydi Köyü’ndeki türbesinin bulunduğu yere gelip yerleşmiş̧tir. 17 yıl burada yaşadıktan sonra 1307 ylında vefat etmiş ve buradaki türbesine gömülmüştür. Hac1 Murad-1 Veli'nin 3 erkek çocuğu olmuştur. En küçük oğlu Halil, babasından önce vefat etmiş ve babasının yanına gömülmüştür. İkinci oğlu S. Veli, Ortaca ilçesine bağlı Elmalık Bucağı'nda "Elvan Çelebi” adı ile bilinen türbede gömülüdür. Üçüncü oğlu S. Zeynel'dir. Hacı Murad Veli'nin nesli bu çocuğundan devam etmiştir. Asıl adı unutulup Pir Ali Çelebi adıyla bilinmektedir. Eskipazar yakınlarında "Sede Yaka" karyesinde bir tekke kurarak o ylllarda büyük âlimler yetiştirmiştir (Teberoğlu, 1998, s. 135140’tan Arslanoğlu, 1999, s. 69-70).

Öncelikle burada özetlenen iki farklı hikâyenin ${ }^{12}$ de sözlü rivayetlere dayandığını belirtmek gerekir. Bu rivayetlerde, onu Horasan tasavvuf geleneğine bağlayan, başka deyişle Yesevî telakki edebilen hususlar üzerinde durmak gerekir. Bu hususlar; 1. Babası, 2. Yaşadiğı dönem, 3. Göc yolu, 4. Mutasavvrfin kendi adı şeklinde sıralanabilir.

\section{Babası}

Sözlü gelenek Hacı Murad-1 Veli’nin babasını Aliyü’l-Büka veya Aliyü’l-Buka olarak göstermektedir. Alevi gelenek bu adın Ahmet ve Ali gibi varyantlarını ileri sürse de ortak isim olan Aliyü'l-Büka üzerinde durmak istiyoruz. Bu ismin okunuşu hakkında farklı bir yorum ise İbrahim Akyol'a aittir. I. Akyol, bu ismi Aliyü'l-Baka şeklinde okumakta ve onun Abdülkadir Geylanî’nin icazet verdiği 16 halifeden biri olan Şeyh Baka (Akyol, 2012, s. 69) olduğunu söylemektedir. Bize göre ise Aliyü'l-Büka veya Aliyü'l-Buka telaffuzu daha doğru olup ismin aslı buka kelimesine dayanmaktadır. Eski Türkçede boğa anlamına gelen ve bugün de Orta Asya'daki pek çok Türk lehçesinde buka şeklinde telaffuz edilen Buka eski Türk onomastik geleneğinden kaynaklıdır. Nitekim eski dönemlerde güçlü hayvan adlarının şahıs ismi olarak tercih edilmesi

${ }^{12}$ Bu hikâyelerin farklı bir varyantı için ayrıca bk. (Yaman, 2005: 156). 
Türklerde yaygın bir gelenekti. Bu yüzden Hacı Murad-1 Veli’nin babasının adı, gerek İslam öncesi dönemde gerekse İslam'ın kabulünden sonra, Türklerde sıkça kullanılan Buka’ya dayanmış olmalıdır.

Bu bağlamda tarihî kaynaklara bakıldığı zaman IX. yüzyllın ikinci yarısı ile X. yüzyılın ilk yarısında bu ismi taşıyan ancak ölüm tarihleri bilinmeyen iki Türk komutanı bulunmaktadır. Zeki Velidi Togan'ın verdiği bilgiye göre bunlardan ilki Büyük Buga isminde olup Halife Mutasım'n görevlendirdiği ve 840 yılında Mençekur’u esir alıp halifeye götürdüğü kişidir (Togan, 1981, s. 176). Bu büyük Türk kumandanı daha sonra 852-855'de Ermenistan ve Azerbaycan valisi olarak atanmıştır (Togan, 1981, s. 177). O dönemde Adana ile Tarsus arasında yer alan Funduk kasabası da komutan Buga'ya aittir (Togan, 1981, s. 178). Ancak Aliyü'l-Buka'nın Çankırı'ya gelinceye kadar takip ettiği göç yolları bu komutan ile uyuşsa da tarih bakımından bir asırlık zaman farkı vardır. Onun için bu Buka'nın Hacı Murad-1 Veli'nin babası olma ihtimali zayıftır. Diğer Buga ise 1040'lı yıllarda galiba gençken aktif olup, Irak Türkmenlerinin reislerinden biridir. Üstelik bu şahıs Musul ve Diyarbakır taraflarına akınlarda bulunmuştur (Togan, 1981, s. 191). 10151036 senelerinde Amuderya ile Dicle arasındaki ülkeleri fetheden bu Buga bir ara Gaznelilere tabi olmuş, daha sonra Yanaltegin'e iltihak etmiştir (Togan, 1981, s. 192). Onun için de Hacı Murad-1 Veli’nin yaşadığ1 tarihlerle örtüssen bu ismin varlığına daha dikkatle bakmak gerekir.

Bu bilgilere göre Irak Türkmenleri reisi olan ikinci Buga'nın 1100’lü yıllara kadar yaşadığı tahmin edilebilir. Tarihî bir şahsiyet olan bu Buka'dan, başka araştırmacılar (Turan, 1969, s. 80; Divitçioğlu, 2004, s. 51) da bahsetmektedir. Bu dönemlerde Alp Arslan Gürcistan'1 fethederken Karategin adlı komutan ise Halep ve Antakya taraflarını fethetmiştir (Togan, 1981, s. 192). Üstelik eldeki bilgiye göre 1065 veya 1068 tarihlerinde Çankırr'yı fetheden bu Karategin'in aslında bir Karahanlı prensi olduğu da ifade edilmiştir (Togan, 1981, s. 197). İşte burada çok önemli bir ipucu yakalamış oluyoruz ki o da bazı rivayetlerde Aliyü'l-Buka'nın Şanlıurfa taraflarında kaldığı yönündeki bilgidir. Bu bilgi aslında Buka'nın o civarlarda bulunması yönüyle tarihî bilgilerle uyuşmaktadır. Bundan ötürü tarihler ve bölgeler dikkate alınınca tarihî bir kişilik olması hasebiyle komutan Bugalardan ikincisinin Hacı Murad-1 Veli'nin babası olma ihtimali yüksektir. Çankırı fatihi Karatekin'den başkası olmadığı anlaşılan Karahanlı prensi Karategin ile kuvvetle muhtemel Buga'nın kendisi olan Aliyü'l-Buka'nın hem tarihî kayıtlarda hem sözlü rivayetlerde ${ }^{13}$ aynı dönemlerde yaşaması ve bu dönemin yaklaşık olarak Ahmed Yesevî zamanıyla örtüşmesi birbirini destekler mahiyettedir.

$\mathrm{Bu}$ tarihsel veriler haricinde tıpkı Osmanlının kuruluşundaki gibi Selçuklunun kuruluşunda da ilk kurucuların yanında dervişler olmuştur. Mesela daha Hemedan taraflarındayken Tuğrul Bey'in Baba Tahir, Baba Cafer ve Şeyh Hamza gibi dervişlerle beraber olduğu ve onlardan dua aldığı bilinmektedir (Divitçioğlu, 2004, s. 52). Acaba bu dervişler arasında Buka yahut Aliyü'l-Buka var mıdı ve bu zat Tuğrul Bey'le beraber Bağdat'a gitti mi? Bu soruların cevabı şimdilik bilinmiyor, ancak bunların, üzerinde düşünülmesi gereken sorular olduğu kanaatindeyiz.

\section{Yaşadığ1 Dönem}

Bu zatın yaşadığı tarihler hakkında da iki farklı bilgi bulunmaktadır. İlk görüşe göre Hacı Murad-1 Veli 1117-1207 tarihleri arasında yaşamıştır. İkinci görüş ise onun yaşadığı tarihleri 1228-1307 olarak kaydetmiştir. İki görüşte belirtilen tarihlerin biraz daha önce veya sonra olma ihtimali de var. 1117-1207 tarihlerinin bir asır sonra yani 1228/1229-1307 olarak verilmesi H. Teberoğlu'na (1998) dayanmış görünüyor. Aslında ilk araştırma olan Karatekin Ulular adlı kitapta yıl da telaffuz edilmemekte, sadece XII. asır zikredilmektedir. Ancak Hacı Murad-1 Veli’nin gerek yüzyıl gerekse yıl bazında yaşadığı ileri sürülen bu dönemleri teyit eden eski bir yazılı belgeye şimdilik rastlanmadığı için bu tarihler varsayımdan öteye gidememektedir.

Bununla birlikte tarihler irdelendiğinde birbirini destekleyen bilgiler ortaya çıkmaktadır. İlk rivayete göre Hacı Murad-1 Veli'nin yaşadığı tarihler Büyük Selçuklu İmparatorluğu'nun dağıldığı, çeşitli devletlere bölündüğü ve Anadolu'da Türk Beyliklerinin aktif olduğu bir döneme rast gelmektedir. Onun son dönemi ise Anadolu Selçuklu Devleti'nin ihtişamlı devrine denk gelmektedir. Hacı Murad-1 Veli'nin Seydi Köy'e yani Çankırı'ya gelip yerleştiği 1187 yılı da Anadolu Selçuklularının hâkimiyetindeki bir devirdir. Bu görüş, Hac1 Murad-1 Veli’nin Moğol istilasından evvel gelen Horasan erenlerinden olduğunu destekler mahiyettedir.

\footnotetext{
${ }^{13}$ Gerek Emir Karatekin'in gerekse Aliyü’l-Buka'nın sözlü gelenekte birer veli olarak telakki edilmesi de bu çerçevede manidardır. Öyle anlaşıllyor ki Emir Karatekin'in komutanlık vasfi halk rivayetlerinde kendini korumuş ancak Hacı Murad-1 Veli’nin mutasavvıf kimliğinden ötürü babası Aliyü'l-Buka'nın bu yönü unutulmuş ve o da sadece Horasan erenleri safinda yer almıştır.
} 
İkinci rivayet ise bu zatın XIII. asırda yaşadığını söylemektedir. Bu dönem ise Moğolların şiddetli saldırılarının olduğu zamanlardır. Ancak Ahmed Yesevî, Karategin, Buka adlı komutanların yaşadığı tarihlerle birleştirince ilk görüş ikinci görüsse göre daha isabetli görünüyor. Bu açıdan İ. Akyol tarafindan

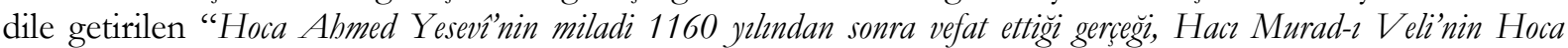
Ahmed Yesevî tarafindan yetistirildiği ve Anadolu'ya gönderildiği görüs̆̈̈nü güglendirmektedir" (Akyol, 2012, s. 69) kanaati isabetlidir. Esas itibarıyla ilk görüşte belirtilen yıllar sırasıyla Bizanslar, Büyük Selçuklular, Türk Beylikleri ve Anadolu Selçuklularının bu bölgede hâkimiyet sağlamaya çalıştığı bir devreye rast gelmektedir. Onun için bu mücadeleler esnasında dinî ve kültürel bir rekabetin yoğun yaşandığ bir dönem olduğu unutulmamalıdır. İște bu dönemde Hacı Murad-1 Veli ve onun gibi diğer manevî mimarların Anadolu’da dinî, sosyal ve kültürel mücadelede önemli rolleri olmuştur.

\section{Göç Yolu}

Sözlü geleneğe göre Ahmed Yesevî’nin dervişi olan Hac1 Murad-1 Veli Anadolu'da pek çok yer gezdikten sonra kendisine Çankırr'ya bağlı Eldivan ilçesinin Seydi Köyü’nü mesken tutmuştur. Zira halk bu sözlü verileri şüphe götürmez şekilde kabul etmektedir. Bu köye gelip yerleştiği göç yolu ise Horasan'dan Mekke'ye ve oradan da Şanlıurfa üzerinden Çankırr'ya doğru çizilmektedir. Göç yolu konusunda hem Sünni hem Alevi kaynaklarında ittifak var, üstelik bu durum tarihî kişilik olan Türkmen beyi Buka'nın fütühatta bulunduğu mekânlarla da uyuşmaktadır. Buna karşın Hacı Murad-1 Veli'nin Eldivan'a yerleşmesinin hikâyesi çeşitlenmektedir.

İlk hikâyeye göre Aliyü'l-Buka Tosya'ya, oradan da Ilgaz Yerkuyu'ya yerleşmiş ve mezarı da oradadır. $\mathrm{Bu}$ bilgilere göre Aliyü’l-Buka'nın oğlu Hacı Murad-1 Veli'nin Ilgaz'dan Eldivan'a gelmiş olması gerekmektedir. Bu göçün halk arasında bilinen bir hikâyesi yok ancak Sünni gelenekte Hacı Murad-1 Veli'nin annesi olduğu söylenen Hatice Sultan'ın Ilgaz ile Eldivan arasında yer alan Korgun'un Handırı (Ahlat) köyünde metfun olması unutulan bir göç hikâyesinin izlerini taşımaktadır. Diğer görüşe göre bu zat Kalecik Eskiköy üzerinden Eldivan’a gelmektedir. Bunun ise dikkat çekici bir hikâyesi var. Söz konusu mutasavvıfın göç hikâyesi ile yaşadığı tarihler arasındaki değişiklik ona yönelik iki farklı bakış açısından (Sünni ve Alevi) kaynaklanmıştır. Ancak hangisinin doğru olduğunu kestirmek gayet güçtür. Fakat Anadolu’ya olan göçün aynı olması onun Horasan'dan geldiğini desteklemektedir.

\section{Mutasavvifin Kendi Adı}

Sözlü rivayette bu zatın ismini alış hikâyesi başka menkıbelerde görüldüğü üzere süslenerek anlatılmaktadır. Bu yüzden ismin alınış öyküsünün menkıbevî olduğu anlaşılmaktadır. Ancak Hacı unvanının dikkatli bir şekilde analiz edilmesi gerekir. İlk tahlile göre, göç yollan da dikkate alınarak, onun hacca gittiği ve onun için de Hacı unvanını aldığı ancak zamanla bu durumun menkıbeyle süslenerek anlatıldığ1 kabul edilebilir. Nitekim Buka'nın Horasan üzerinden güneye doğru ve oradan Musul ve Diyarbakır'a kadar seferler düzenlemesi onun Mekke'ye gidip hacı olma ihtimalini de güçlendirmektedir. Bununla birlikte bu unvanın hacıdan ziyade Farsça hoca anlamına gelen hâce olması ve zamanla hacıya dönüşmesi bize daha mantıklı gelmektedir. Zira Orta Asya tasavvuf geleneğinde çok sık görüldüğü üzere, tıpk1 Hoca Ahmed Yesevî gibi, bu zatın Hace (Hoca) Murat olması gerekir. Nitekim Abdülhalik Gücdüvanî’nin kurduğu sisteme hacegan yani hocalar denmiş ve Yusuf Hemedanîden itibaren neredeyse XVII. yüzyıla (Hace Ubeydullah Ahrar gibi) kadar bu unvan kendini korumuştur. Bu unvanın kullanılış sebebi ise zahirî ve batınî ilimlerde olan yetkinliktir. Onun için de dinî ilimlerde yetkin olan Hoca Ahmed Yesevî gibi Hoca Murad-1 Veli daha mantıklı bir çıkarım olsa gerektir. Orta Asya'daki mutasavvıfların çoğunun hacıdan ziyade hâce (hoca) unvanlı olması da bu anlamda manidardır.

Veli kavramının izafe edilme sebebi muhtemelen "veli kültü"yle ilişkilidir. Murad-1 Veli terkibi ise Farsça kaynaklıdır. Çünkü hem tasavvuf tarihinde hem de Anadolu'da pek çok zatın adı bu terkibe göre anılmış ve bu durum son dönemlere kadar devam etmiştir: Farslı Bestamlı Bayezid anlamında Bayezid-i Bestami, Çerhli Yakup anlamında Yakub-1 Çerhi, Arvaslı Abdülhakim anlamında Abdülhakim-i Arvasi gibi. $\mathrm{Bu}$ tahlile göre mutasavvıfin adı Hace (Hoca) Murat olup, halk arasında kendisi veli olarak kabul edildiği ve bu dönemde adların yaygın kullanımı Farsçaya uydurulduğu için ismi Hace Murad-1 Veli olarak telaffuz edilmiş ve isim zamanla Hacı Murad-1 Veli’ye dönüşmüş olmalıdır.

\section{Sonuç}


Tasavvuf, İslam dininin özüne uygun yaşanması için ortaya çıkan bir kurumdur. Bu kurumun müşahhas şekli ise tarikatlarla ifade edilmiştir zira tarikatlar ortaya çıkış ve gelişme sürecinde somut isimler ve yaptıkları faaliyetlerle toplumda kendine yer edinmiştir. Bu bağlamda tasavvuf tarihinde Horasan'ın önemli bir yeri vardır. Özellikle burada gelişen tasavvuf cereyanı Türklerin İslam’la ilişkisini olumlu yönde etkilemiş ve Horasan Türk tasavvuf geleneği ortaya çıkmıştır. Bunun en önemli temsilcisi olan Ahmed Yesevî ise çok sayıda derviş yetiştirmiş ve onları çeşitli bölgelere yönlendirmiştir. Yesevilliğe ilişkin kaynaklara göre onun pek çok dervişi Anadolu'ya da gelmiştir. Hacı Murad-1 Veli, gelenekte bunlardan biri olmasına rağmen maalesef doğrudan ondan bahseden veya onu yeterince tanıtan yazllı belgeler mevcut değildir.

Sözlü rivayetler ise onun XII. veya XIII. yüzyılda Türkistan'dan gelerek Hicaz, Şam ve Şanlıurfa civarlarına, sonra da Tosya ve Çankırı yörelerine yerleştiğini ve Horasan'dan gelen bir Yesevî dervişi olduğunu söyler. Yine rivayetlere göre Hac1 Murad-1 Veli, Aliyü'l-Buka'nın oğlu olup, muhitinde İslamiyet'in yayılması için çalışmıştır. ${ }^{14}$ Çocukları olduğu tahmin edilen kimselerin zaviye ve mescitlerine ait yazılı belgelerin ortaya çıkması bu yöndeki düşünceleri teyit etmektedir. Annesi ve eşi hakkındaki bilgiler çok az olup, babası ve çocuklarına dair görüşler ise çeşitlidir. Nitekim Sünni ve Alevi gelenek bunlarla ilgili farklı bilgi vermektedir. Ancak iki geleneğin hem babasını aynı kişi olarak göstermesi hem de onu Horasan'dan gelen bir Yesevî dervişi olarak kabul etmesi bu bilgilerin gerçeğe dayalı bir hikâyenin ipuçlarını vermektedir. Somut kültürel unsurlar da Hacı Murad-1 Veli’nin Yesevîlik ve Horasan bağlantısını işaret etmektedir.

Neticede Hacı Murad-1 Veli hakkında net bilgi veren kaynaklar bulunmasa da onun Ahmed Yesevî ve Horasan tasavvuf geleneği ile bağlantılı olma ihtimali yüksektir. Zira Hacı Murad-1 Veli gibi Anadolu'nun fethiyle birlikte Çankırı ve havalisinde Sarı Yanık Baba, Şeyh Yunus, Toprak Baba, Er Duran (Aydın, 2010: 43) vb. gibi pek çok erenin ${ }^{15}$ bulunması burada Horasan tasavvuf geleneğini işaret etmektedir. Nitekim babası Aliyü'l-Büka'nın Türkistan, Şam, Hicaz, Urfa ve nihayetinde Tosya ve Ilgaz şeklinde takip ettiği yol da bu mutasavvıfın menşeini Horasan'a çıkarmaktadır. Kendisi gibi babasının da Hoca Ahmed Yesevî ile büyük ihtimalle bir bağlantısı mevcuttur. Şimdilik elde edilen malzemelerin içinden sözlü rivayetler ile somut kültürel ürünlerden hareketle Hacı Murad-1 Veli'nin Horasan'dan gelen bir Yesevî dervişi olduğu düşünülebilir. Yine o dönem Türk tarihinde Buka adlı bir komutanın hem Hacı Murad-1 Veli’nin babasıyla benzeri adı taşıması hem de Emir Karatekin'le aynı dönemde ve birlikte hareket etmesi diğer verileri destekler niteliktedir.

\section{Kaynakça}

Aktaş, C. (2011). Çankırı tasavvuf tarihine genel bir bakış. Çankırn Arașturmalarr, 8, 45-52.

Akyol, İ. (2012). Beylikler döneminde Çankırr'da dini-tasavvufi hayat. Kuгey Anadolu'da Beylikler Dönemi Sempossyumu Bildiriler, Çankırı Karatekin Üniversitesi Yayınları, (Editör: Dr. Halil Çetin), Çankırı, 65-78.

Arslanoğlu, İ. (1999). Çubuk yöresi alevi ocakları ve kurucuları. Türk Kültürü ve Hacı Bektaş Velí Araștrma Dergisi, 10, 61-72.

Aydın, E. (2010). Çankırnlı Bir Yesevî Dervişidir Hacı Murâdı Velì. Çankırı: Karatekin Ofset Matbaacılık.

Ayhan, B. (2012). Seydiköy-Hacı Murad-1 Veli Türbesi. Çankırn İnanç Rebberi, Çankırr: Çankırı Belediyesi Kültür Yayınlar1, 110-112.

Ayvalli, R. vd. (2004). Orta Anadolu evliyalarr. İstanbul: Türkiye Gazetesi Yayınları.

Barkan, Ö. L. (y.t.y.). Kolonizatör Türk dervişleri. İstanbul: Hamle Yayın Dağitım.

Başer, T. (y.t.y.). Hacı Murad-1 Veli. Karatekin Ulular, Ankara: Ajans-Türk Matbaası, 16-19.

Çetin, O. (1998). Horasan. İslam Ansiklopedisi, Ankara: TDV Yayınlar1, 18, 234-241.

Eraydın, S. (1990). Tasavvuf ve tarikatlar. İstanbul: Marifet Yayınları.

Güzel, A. (2012). Dinî-tasavvufî Türk edebiyatı el kitabı. Ankara: Akçă̆ Yayınları.

İpçioğlu, M. (2009). Çankııı evkaf defterlerine göre 1864 yılında Çankııı sancağında bulunan vakıfların mart ayına ait hasilatlarına dair. Cankerr Arasturmalar Dergisi, 4, 15-18.

Kankal, A. (2005). 16. yüzyıl idarî taksimatında Çankırı sancağı ve Çankırı kazası. Geçmişten Geleceğe Cankırr/III. Çankırı Kültürü Bilgi Ş̈̈leni Bildirileri, Çankırı Valiliği Yayınları, 185-216.

Kankal, A. (2011). XVI. yüzynlda Çankırr. Çankırı: Çankırı Belediyesi Kültür Yayınları.

Karadut, M. (2007). Hacı Muradıı Veli Seydi Köyü. Çankırı: Yıldız Matbaası.

Karadut, M. (2014). Horasan Erenlerinden Hacı Murad-ı Veli H₹: Çankırr: Kayıkçı Mat. Yay. San. Ltd. Şti.

\footnotetext{
${ }^{14}$ Kanaatimize göre konuya ilişkin hemen her eserde geçen bu bilgiden, Hacı Murad-1 Veli’nin gayrimüslim muhitte yaşadığı ve onları İslam'a davet ettiği kastedilmektedir.

15 A. Y. Ocak (1997: 34) eserinde zikredilen isimlere benzer çok sayıda veliden bahsetmekte ve onların gerçekten var olup olmadığını tartışmaktadır.
} 
Kökel, C.-Ersal M. (2008). Çankırı ilindeki alevi köyleri hakkında. Türk Kültürü ve Hacı Bektaş Velî Araştırma Dergisi, 48, 13-54.

Köprülü, F. (1976). Türk edebiyatında ilk mutasavnflar. Ankara: Diyanet İşl. Bşk. Yayınları.

Ocak, A. Y. (1997). Menakıbnameler. Ankara: Türk Tarih Kurumu Yayınları.

Şahin, G. vd. (2014). Cankır kültür envanteri. Ankara: Çankırı Valiliği İl Kültür ve Turizm Müdürlüğü Yayınları.

Taş, H. (2000). Bursa şehitler köyü halk kültüründe Hasan dede ve çevresinde oluşan inanç ve gelenekler. Uluslararası Anadolu Inançlar Kongresi, Ervak Yayınları, 707-730.

Tatc1, M. (1997). Edebiyattan içeri/ dini tasavvufi Türk edebiyatı üzerine yažlar. Ankara: Akçağ Yayınları.

Teberoğlu, H. (1998). S. Kalender Veli velayetnamesi. Ankara: Kale Ofset.

Topkaraoğlu, N. (1991). Çankırı merkez ve ilçelerinde yapılan eski eser tespit çalışmaları 3. VIII. Vakıf Haftası Kitabı. Ankara: Vakıflar Genel Müdürlüğü Yayınları, 153-164.

Turan, O. (1969). Selçklular taribi ve Türk-İslam medeniyeti. İstanbul: Turan Neşriyat Yurdu.

Yaman, A. (2005). Hoca Ahmet Yesevi ile bağlantılı ve literatürde az bilinen alevî-bektaşî erenleri. Türk Kültürü ve Hacı Bektass Velî Araștırma Dergisi, 35, 145-160.

\section{EXTENDED ABSTRACT}

Sufism is an institution that emerged to lived according to the essence of Islam. The concrete form of this institution is expressed by the sects. Because the sects, in the process of emergence and development, with individuals and their activities have taken a place in society. For him, Khorassan played an important role in the history of Turkish mysticism. In particular, the mysticism school that developed here affected the Turkic people relations with Islam positively. Consequently, the Turkish Sufism tradition of Khorassan emerged. The Turkish Sufism tradition is generally started in Central Asia with Ahmed Yasawi, Ahmed Edib Yüknekî, Hâkim Süleyman Ata etc. The representatives of this tradition gave importance to the subjects such as religious, moral, judicial and literary in their works. Members of the same tradition continued this situation too when Turks migrated to Anatolia. In this context, the spread of the Turkish mysticism tradition to Anatolia was first of all realized with Ahmed Yasawi and his caliphs. Yasawiyyah, which was initiated by Ahmed Yasawi, became widespread among Turks. Yasawiyyah was moved from Central Asia to Central Europe by his caliphs. Thus, Yasawiyyah has contributed both to the Turkification of Anatolian lands and has served to settle of Islam here. As a matter of fact, Ahmed Yasawi sent many own caliphs to different regions where Turks lived. Among the his caliphs who came to Anatolia, there were many people like Pir Dede, Akyazıll, Emir Çin Osman, Şeyh Nusret and Gajgaj Dede and they were active in Northern Anatolia. Therefore, Chankiri became one of the first places where Yasawiyyah was spread. According to the oral tradition, there are many Yasawiyyah representatives in Chankiri, such as Sarı Yanık Baba, Şeyh Bahaeddin, Şeyh Mehdi, Ali Turabi Baba, Aliyü'l-Büka. In the oral tradition, it is stated that Hadji Murad-i Veli was also a Yasawi darwish. However, it has not been possible to come across a clear sign about him in the written documents. There is not enough information in the written documents about Hadji Murad-i Veli, nevertheless some research has been done about him until now. Some of these studies are scientific and some are also amateurish researches. All of these works are valuable because there are not enough written sources about this mystic in the early period of Turkish mysticism literature. Because, in these studies, at least the information crumbs about this person have been compiled. However, these studies did not address the issue systematically and could not elicit a clear solution to the problem. In this research, studies on Hadji Murad-i Veli were meticulously compared, criticized and all sources related to it were evaluated. In short, existing materials are handled with a systematic methodology. In this context, in this study, on this mystic, written documents (hand writing, archival documents, foundations, etc.), material culture elements (mosque, tomb, Khorasani headwear, etc.) and oral folk narrations (legends of saint, folk songs, etc.) were examined together. In addition, historical information given by historians was also evaluated. In addition, the information passed from the oral tradition was also benefited, and so it is discussed whether Hadji Murad-i Veli was a Yasawi darwish. Accordingly, there are two legends that constitute the basis for the biography based to fiction of Hadji Murad-i Veli. The life story of this mystic lived in small but important nuances in Sunni and Alevi traditions. Alevi sources tell the story of the settlement of Hadji Murad-i Veli to Eldivan Seydi Village from city Kalecik. Sunni sources indicate that this are realized through Tosya-Ilgaz. According to the Sunni tradition Hadji Murad-i Veli's father Aliyü'l-Büka was buried in the Yerkuyu Village of Ilgaz. The tomb of Hatice Sultan, his mother, is also in Korgun district between Ilgaz and Eldivan. In addition, documents on the Hadji Murad-i Veli foundation were found on the Tosya side. In fact, the different stories described in the two traditions seem to complement the biography of Hadji Murad-i Veli. Indeed according to the Alevi tradition, he was sent to Anatolia as the imam of the Akkoyunlu tribe. The 
"karaağaç köse" thrown from Khorassan was found in the place known as Eskiköy and Hadji Murad-i Veli settled here. He lived in Eskiköy for a long time, but was subjected to the persecution of the Kalecik lord. For this reason, he came in Seydi Village, a district of Eldivan, Chankiri and settled here. As a result, Hadji Murad-i Veli in the XII. or XIII. century, came from Turkestan to Hijaz, Damascus and Shanliurfa. Then settles in Tosya or Kalecik (Chankiri) region. According to tradition, he is a Yasawi darwish from Khorassan. Again according to the reports, Hadji Murad-i Veli was the son of Aliyül-Büka and worked for the spread of Islam in his neighborhood. In this context, he has a document of foundation. Written documents of the children's zawiya and masjids have also appeared. These confirm ideas of about spreading Islam by him. There is little information about his mother and his wife, and views on his father and children are diverse. The Sunni and Alevi traditions give different information about them. However, the two traditions both refer to his father as the same person and accept him as a darwish of Yasawi from Khorassan. These information gives the clues of a truth-based story. Again, concrete cultural elements indicate the connection of Hadji Murad-i Veli with Yasawiyyah and Khorassan too. 